\title{
Aneta Bołdyrew
}

Faculty of Educational Science, University of Łódź (Poland)

\section{MERITED, (UN)APPRECIATED, (UN)REMEMBERED: WOMEN IN EDUCATIONAL AND SOCIAL POLICY SCIENCES AS A SCHOLARLY DISCIPLINE IN POLAND, 1900-39}

\begin{abstract}
The first four decades of the twentieth century saw an intense development in the Polish lands of educational sciences and social policy sciences. A role of importance in the development of the underlying theory for these scientific domains and in the pursuit of pioneering empirical studies fell to a group of women who combined their intellectual interests and scientific research with activities in the fields of education and social work. This article seeks to outline their scholarly achievements (until 1939) and point to the specificity of their effort: none of them pursued a 'classical' academic career comprehended in terms of getting employed and promoted by a university. Their formative experience consisted in studying abroad and obtaining their doctoral degrees there. Migrations and membership in (or contribution to) international scientific organisations enabled them to deepen their knowledge and present their theories in the international forum whilst also making them acquainted with the academic models functioning in West European countries in the context of female participation. The personal histories of Polish female scholars researching into education and social history show the 'typical' experience of reluctance and arbitrariness of the academic circles, male-dominated as they were at that time when gender weighed high on career-seeking in science. This implied search for strategies and areas of activity which enabled to participate in the world of science. Pursuance of research, in selected areas, and publication of scholarly texts was enabled through the cooperation with organisations which welcomed female experts such as those employed (for example) with ministries; the Polish Society for Social Policy was one such organisation. In spite of multiple hindrances and restrictions, those female scholars who got employed on a full-time basis with academies which were 'alternative' to the traditional universities the Institute of Special Pedagogy, the State Institute of Teachers, and primarily, the Free Polish University - enjoyed the most favourable conditions of work.
\end{abstract}

Keywords: Polish female scholars, history of science, educational sciences, social policy 


\section{I \\ INTRODUCTION}

The early twentieth century saw in the Polish lands an intense development of educational sciences and social policy theory. In the Polish realities at the end of the nineteenth century, characteristic of educational sciences was a syncretic blend of idealistic and utilitarian assumptions. In parallel, in the late nineteenth /early twentieth century, empirical and experimental pedagogy advanced, seeking inspiration in the Western scientific pedagogy. Paedology emerged at the beginning of the twentieth century as an interdisciplinary experimental science on child and their physical, psychical, and educational development. Interest was growing in the theory of paedocentrism, which was propagated in West European countries and in the United States by pedagogues of the reformist movement called 'New Education'; original concepts in this respect were created by a number of Polish pedagogues, Janusz Korczak and Henryk Rowid among them. In the first two decades of the twentieth century Stanisław Karpowicz popularised scientific pedagogy based on social foundations and further developed through socio-pedagogical research conducted by Helena Radlińska and other scholars. The cultural pedagogy trend burgeoned no less intensely: also called pedagogical personalism, the trend was represented at that time by Bogdan Nawroczyński and Sergiusz Hessen. ${ }^{1}$ Social care issues were strictly connected with those of education. The difficult political and socioeconomic situation that prevailed in Polish lands during the partitions and after the First World War implied wide interest in the questions of poverty and marginalization, thus giving impulses to a theory of social policy.

Pedagogical issues and social policy problems were the focus of interest also for those women who were eager to satisfy their intellectual aspirations and expected to be given access to studies and to unrestrictedly pursue academic activities. Essential to the building of a climate favouring the acceptance of these postulates, which undermined the essentialist foundation for the socialisation of women, was the activity in education and instruction, popularisation of knowledge and pursuit of research by a group of female educationalists in the late nineteenth/early twentieth century. The group was formed by

${ }^{1}$ Stefan Wołoszyn, Nauki o wychowaniu w Polsce $w$ XX wieku: próba syntetycznego zarysu na tle powszechnym (Kielce, 1998). 
women who in Polish lands before 1890 had no opportunity to be formally educated to an academic standard but eventually, despite the circumstances, made themselves into scholars and scientists through self-instruction and self-study. Let us remark that some of those 'self-made women' were temporarily or systematically supported by their partners. In the scholarly fields concerned, the most eminent among these 'intellectuals with no academic qualification' was Aniela Szycówna (1869-1922), who excelled in the number of empirical studies carried out and academic publications to her credit, involvement in the development of a network of contacts between female movement activists, initiation of research in the role of women in pedagogical activities. ${ }^{2}$ Szycówna took efforts to build a community of female researchers through organising team-based research, including within the confines of a Society for Research of Children, established 1907. She integrated the milieu of women who dealt with children and youth professionally as well as a voluntary community service - including pedagogues, physicians, and educationalists. ${ }^{3}$ In 1912 female members accounted for 75 per cent regular members of the organisation. ${ }^{4}$ In spite of no academic qualification she could boast, Szycówna was a 'citizen of knowledge', and her case is an important element in Poland's history of educational and scientific emancipation of women. ${ }^{5}$

This article seeks to delineate the achievements of women who had their academic education completed and whose role in the development of educational sciences and social policy as a scientific discipline in the first decades of the twentieth century (until 1939) was highly important or essential. The other objective is to determine the characteristics of the work of the female scholars of whom none pursued the 'classical'

${ }^{2}$ Aniela Szycówna, Kobieta $w$ pedagogice: matka (Warszawa, 1908); Irena Kosmowska, Dorota Milkuszyc and Aniela Szycówna, Kobieta polska jako autorka pedagogiczna: bibljografja książek z dziedziny teorii wychowania, podręczników i literatury dla mtodzieży, poprzedzona wstępem historycznym (Warszawa, 1912).

${ }^{3}$ State Archives in Łódź, Archive of K. Walewski of Tubądzin, class. no. 86.

${ }^{4}$ Pamiętnik Polskiego T-wa badań nad dziećmi za rok 1912 (Warszawa, 1913), 32-3.

${ }^{5}$ Szycówna emphasised the need for women to be included among scholars in the field of educational issues: "Removed into the depth of family life, having no access to the sources of higher science, woman was for the long ages practically involved in educating the young generation, taking no part in considering the intricacies of pedagogical sciences": Kosmowska, Milkuszyc and Szycówna, Kobieta polska, 4. 
academic path, in terms of official employment status and promotion within a university. ${ }^{6}$ Their ways to the activities in the field of science, the circumstances of their scientific work and, for the intellectuals who worked at the Free Polish University, the conditions of educating the students form altogether an interesting issue from the standpoint of the history of science, history of gender, and history of education. The difficulties the group of females in question encountered in fulfilling their academic aspirations illustrate a broader trend. Like in a number of other countries, also in Poland the mechanisms of exclusion from the academic milieu concerned women who were active in other areas of knowledge. Correspondingly, in other areas of science women looked for strategies allowing them to become scholars and experts. This article will briefly present certain figures of women who, having graduated from a university, embarked upon a career commensurable with their certified qualifications and exhibited activity in the field of research activity and in popularisation of knowledge as far as educational sciences and social policy were concerned. A more detailed analysis will be applied with academic biographies of women whose contribution in the development of the disciplines concerned has proved durable: for the most part, the contribution was vital to Polish academia, though some of the female scholars, notably Józefa Joteyko and Helena Radlińska, played a remarkable role in the advancement of European science. The directions and forms of the activities pursued by Radlińska are worth mentioning: through elaborating her own strategies of academic as well as didactic and organisational actions, she built a new discipline of knowledge: namely, social pedagogy.

II

\section{ACADEMIC PEREGRINATIONS}

The new conditions for the women aspiring for participation in the creation of knowledge were opened through the opportunity to study and, in particular, to be promoted to a doctor's degree. Academic education, whose pursuit required, in most cases, making a trip,

${ }^{6}$ Bibliographical references are quoted in these notes to texts of the less-known (female) researchers. Apart from certain special cases, I quote no titles of the studies by those intellectuals whose output was particularly abundant and is well recognised (Helena Radlińska, Zofia Daszyńska-Golińska, Józefa Joteyko, and Maria Grzegorzewska among them). 
was a particularly important stage in an aspiring woman's life. Many a woman who most significantly contributed to the development of pedagogical disciplines and knowledge on social policy in Poland soil undertook studies at Swiss universities. Quite a number of them completed their studies with a doctor's degree. In terms of versatility of academic interests and number of publications to her credit, Zofia Daszyńska-Golińska, née Poznańska (1866-1934), excelled when still a student. She enrolled in 1885 with the Philosophical Faculty in Zurich to study political economy and economic history; she was moreover keen on historical demographics. She got her PhD in 1892 based on the dissertation entitled Die Bevölkerung von Zürich im XVII Jahrhundert. Ein Beitrag zur historischen Städtestatistik. ${ }^{7}$ In the 1890s she studied in Vienna and Berlin, where she gained extensive knowledge in the sociology, economy, statistics, demography, and philosophy. Acquaintance with various theoretical and methodological concepts inspired her to have her own considerations in the field of theory of empirical studies published; 1892 saw her publish in Warsaw an innovative study on methodology of social, economic, and historical-statistical studies, which she had written alongside her doctoral thesis. ${ }^{8}$

During her course of studies in social sciences at the Zurich and Berlin Universities, Ewelina Wróblewska (1870-1945) likewise proved herself as an active scholar: she had an article on Gabriel Tarde's sociological ideas published in Archiv für Geschichte der Philosophie. In 1897, she received a PhD from the University in Bern, Switzerland, with a thesis on new currents in French national economy. ${ }^{9}$

A number of women of Jewish descent from Austrian Galicia and the Kingdom of Poland studied economy and law at Swiss universities. Melania Bornstein-Łychowska (1874-1962), née Bergson, born to an assimilated Jewish family, graduated in Legal Sciences the University of Zurich as a $\mathrm{PhD}$ in $1899 .{ }^{10}$ Economic and legal sciences at the University of Berlin and thereafter Zurich went to the credit of Maria

${ }^{7}$ http://www.matrikel.uzh.ch/active//static/17001.htm [Accessed: 5 Jan. 2018].

${ }^{8}$ Zofia Daszyńska-Golińska, Szkice metodologiczne: zastosowanie obserwacyi i eksperymentu $w$ naukach gospodarczych: kilka stów o metodzie statystyki historycznej (Warszawa, 1892).

${ }^{9}$ Stanisław Grabski, Pamiętniki, i (Warszawa,1989), 103; Włodzimierz Wincławski, Stownik biograficzny socjologii polskiej, iv (Toruń, 2011), 190.

${ }^{10}$ www.matrikel.uzh.ch/active//static/25281.htm [Accessed: 5 Jan. 2018]. 
Lipszyc-Balsigerowa (1870-1944), who obtained her $\mathrm{PhD}$ in Legal Sciences (1902) under the tutelage of Henrich Herkner, co-founder of the German Sociological Society. ${ }^{11}$ It was Professor Herkner that tutored the doctoral thesis also of Helena Landau-Bauer (1871-1942), who came from the Cracow-based family of Feliks Gumplowicz and Zofia née Goldman. She studied economy and law at the Universities in Zurich and Vienna, completing her studies in 1906 with a PhD from the Faculty of Law at the Zurich University. ${ }^{12}$

Women who in their early youth years worked as teachers, which enabled them to pay for their studies, studied at a number of foreign universities (as well as in those of Galicia). German and Swiss universities offered intellectual formation to some females who later on were active as scholars in areas of pedagogy and social studies. Ludwika Dobrzyńska-Rybicka (1868-1958) began her philosophical studies at age thirty-five with the University of Zurich, which she followed up in Leuven, Paris, and Oxford. She got her $\mathrm{PhD}$ degree in 1909 with the Zurich University. ${ }^{13}$ Maria Kolabińska's (1879-1957) road to the Academia was similar: in 1905, she enrolled with the Philosophical Faculty of the Jagiellonian University, and in 1907 travelled to Lausanne to eventually receive her doctoral degree in Social Sciences in 1912. ${ }^{14}$

French universities offered opportunities for Polish women to pursue their academic careers as well. Following her studies in Geneva and Brussels, Józefa Joteyko (1866-1928), one of the most eminent Polish scholars, continued her studies in Paris and submitted her PhD dissertation there in 1896 to get her 'Doctor of Universal Science in Medicine' degree. A similar peregrination fell to the lot of Maria Grzegorzewska (1888-1967), who started her academic education

${ }^{11}$ Zofia Noworól, 'Maria Lipszyc-Balsigerowa - zapomniana matka polskiej socjologii empirycznej', in Ewa Furgał (ed.), Krakowski Szlak Kobiet. Przewodniczka po Krakowie emancypantek, iv (Kraków, 2012), 217-18.

12 Zbigniew Landau, 'Landau-Bauerowa z Gumplowiczów Helena', in Emanuel Rostworowski (ed.), Polski Stownik Biograficzny, xvii (1971).

${ }^{13}$ Michał Boksa, 'Spuścizny konserwatorów zbiorów, kierowników i dyrektorów Biblioteki Poznańskiego Towarzystwa Przyjaciół Nauk', Biblioteka, xv (2011), 79-80.

${ }^{14}$ Łukasz Dominiak and Włodzimierz Wincławski, 'Życie i dzieło Marii Kolabińskiej. Zapomniany epizod socjologii polskiej’, Roczniki Historii Socjologii Polskiej, ii (2012), 126. 
with the Jagiellonian University; in 1913, she joined the International Paedological Faculty set up and run in Brussels by Joteyko. Grzegorzewska further on studied in London and then at the Sorbonne; having studied psychology there, she submitted a doctoral thesis in philosophy, entitled A study in the development of aesthetic feelings. Research in experimental aesthetics carried out amongst school students in Brussels, in 1916. Grzegorzewska's friendship with Joteyko proved crucial to the development of her career path, from her student years onwards. A similar career was in store for Maria Lipska-Librachowa (1878-1955), who attended the Faculty of Social Sciences at the University of Brussels, where she received her doctor's degree in Pedagogy in 1910. Afterwards, she studied psychology under Józefa Joteyko's tutelage, and crowned this stage of her studies with a Doctor of Paedological Sciences degree in 1913. ${ }^{15}$

The excited aspirations among women for higher-level education, which usually implied the desire to travel to one of the Western universities, were not parallel to a change in the horizon of their possibilities: many a woman failed to fulfil such an intention in the late nineteenth or early twentieth century. The opportunity to embark on studies abroad was restricted by multiple factors, including availability of means, command of the language of instruction, appropriate health condition, personal predispositions, and acceptance of the idea by the family. Migrations during the studies and obtaining of doctoral degree was a formative experience, which was decisive in terms of choices made later on in life. Apart from deepening one's knowledge, studies at a West European university enabled to learn the Western academic model in the context of forms of female participation. This exerted an essential influence on the attitudes of female graduates of Western universities towards various areas of public life (quite a number of them involved themselves during their studies in social and political activities) whilst also reinforcing the conviction that democratisation of the prevalent social model was a must and that egalitarian access to education and science.

The number of Polish women educated at Russian universities and later on specialising in social and pedagogical sciences was rather low; one such was Adela Stefanowicz (1887-1961), who after graduation

${ }^{15}$ Wanda Bobrowska-Nowak and Danuta Drynda (eds.), Słownik pedagogów polskich (Katowice, 1998), 118. 
from a junior high school (gimnazjum) in Vitebsk and completion of a bookkeeping course in Moscow in 1912 undertook studies in psychology and philosophy at the University of Moscow, where she submitted a graduation thesis in 1917. ${ }^{16}$ Halina Krahelska (1886-1945) studied the humanities at Women's Higher Courses at the Odessa university and afterwards in Kiev.

A large group of women attended Polish universities as well namely, those of Cracow and Lwów. Again, for many, such destinations implied the need to peregrinate. Among the female graduates of Galician universities who in the later years were merited in the field of educational sciences and social policy sciences, were those who came from the Kingdom of Poland; one of them was Helena Radlińska (1879-1954), who after her escape from the exile in Siberia in late 1906, together with her husband, settled down in Cracow. Once there, she undertook studies in mediaeval history at the Jagiellonian University, which she completed in 1911. In parallel, she developed her interest in the issues of education, including as member of the 'Adam Mickiewicz' Society of People's University and through her social activities. ${ }^{17}$ Irena Pannenkowa (1879-1969) attended the Philosophical Faculty of the Lwów University to study philosophy, mathematics, and natural sciences; her study written under Kazimierz Twardowski's tutelage and published in the philosophical review Przeglad Filozoficzny was recognised as a doctoral dissertation. ${ }^{18}$

Graduation, doctoral degree obtained, texts getting published in scientific periodicals did not pave the way open for further activity in the area of science, given the masculinised academic space in the early years of the twentieth century. No opportunities were open for employment with a university or promotion in academic institutions. The exclusion mechanisms in Academia circles affected many a female student; one case in point was Maria Kolabińska, whose graduation study, ${ }^{19}$ received with respect by Western European experts and quoted by the scholars of the time, never became a ticket to a genuine career. It was easier to break the exclusivity of knowledge than to alter

${ }^{16}$ Józef Swastek, 'Adela Stefanowicz', in Andrzej Romanowski (ed.), Polski Stownik Biograficzny, xliii (2005).

${ }^{17}$ Wiesław Theiss, Radlińska (Warszawa, 1984), 22-4.

${ }^{18}$ Włodzimierz Wincławski, Stownik biograficzny, iii (Toruń, 2007), 114.

${ }^{19}$ Marie Kolabinska, La circulation des élites en France, étude historique depuis la fin du XIe siècle jusqu'à la grande Révolution (Lausanne, 1912). 
the gender order in the Academia: the latter remained inaccessible to women as a potential employer. No prospects for $\mathrm{PhD}$ holders to follow up their research activity with the alma mater inspired a search for opportunities aside the established scientific structures or within alternative academic institutions where they could perform their professional and scientific work tantamount with their actual, and certified, skills and qualifications.

\section{III \\ OFF-ACADEMIA (FEMALE) EXPERTS}

Given the male domination in the academic world, a considerable number of female graduates in humanities, social and legal sciences, sought jobs with education institutions, offices, social or political organisations, acting as experts - at once or with time. In their will to combine a career with an opportunity to actively popularise knowledge and carry out research, before 1914, they would usually arrive in Warsaw or Cracow, the hubs where intelligentsia milieus were strong. In Warsaw, many a woman was employed with the Warsaw Charity Society. In parallel, most of them pursued journalistic activities, writing articles on the issues they explored during their studies, translated foreign-language texts concerning economy, social policy, philosophy, pedagogy/education studies, and psychology. They had reviews published, particularly on dissertations or discourses authored by foreign experts whose works they were acquainted with in the course of their studies. A bigger chance to find a job corresponding with their actual qualifications came out for them when institutions of the newly-emerged Polish state were being built. Those excellently educated experts in social, economic, and pedagogical issues proactively contributed to the process. Women employed with public institutions helped transfer the knowledge into nonacademic areas of social life.

A group of Polish women who gained their doctorates with foreign or Polish universities worked for the State Inspectorate of Labour and the Ministry of Religious Confessions and Public Enlightenment [sc. Education]. Halina Wittlinowa, née Handelsman (1900-94) worked as a clerk and research scholar with the latter institution; her activities prove how well female intellectuals tackled the tasks whose substance and character went far beyond the skills acquired during their studies. 
Wittlinowa was a Warsaw University graduate and $\mathrm{PhD}$ holder in Polish Philology. With the Ministry, she was member of the staff of the Statistical Section, and thus her responsibilities included gathering and elaboration of quantitative material related to education. ${ }^{20}$ She moreover carried out, on her own, statistical research into the population of Polish students, and had an atlas of tertiary education (Atlas szkolnictwa wyższego) issued (in 1937); ${ }^{21}$ the industry periodical Oświata $i$ Wychowanie published her articles on academic training, including female participation in it. ${ }^{22}$

A batch of female university graduates got employed with the Ministry of Labour and Social Care; some worked there for a number of years. Maria Kolabińska was employed in 1919 as Deputy Inspector for Labour with the Ministry's Inspection Unit; in 1928 she was promoted to manager of the Female and Juvenile Labour Section, and enjoyed reputation as an excellent expert. ${ }^{23}$ Melania BornsteinŁychowska, another long-standing member of the Ministry's staff, was an outstanding specialist as well. She started her career with the Female and Juvenile Labour Section in 1918 as a clerk assistant, and concluded it in 1938 as a department manager. Her first superior was Zofia Daszyńska-Golińska, who had a two-year full-time record with the Ministry before she quit, but during her employment she played an important part in empirical research into women's living and labour conditions; her invited research associates included her Ministry co-workers, Bornstein-Łychowska among them, as well as female movement activists, including Cecylia Walewska. ${ }^{24}$ Lipszyc-Balsigerowa and Krahelska were among the Ministry's female staff who did research in labour conditions among adolescents and women and in the situation of the jobless. A deputy to the Chief Labour Inspector for protection of female and juvenile labour with the Ministry of Labour and Social Care, Krahelska used the opportunity of a Rockefeller scholarship to visit in 1929 Switzerland, France, Austria, and Germany in order to learn more about labour protection and social care systems functioning in

\footnotetext{
20 Włodzimierz Wincławski, Stownik biograficzny, iv, 167-8.

${ }^{21}$ Halina Wittlinowa, Atlas szkolnictwa wyższego (Warszawa, 1937).

${ }^{22}$ Eadem, 'Udział kobiet w studiach wyższych', Oświata $i$ Wychowanie, vi (1936), 449-54.

${ }^{23}$ Dominiak and Wincławski, ‘Życie i dzieło Marii Kolabińskiej’, 126.

${ }^{24}$ Renata Owadowska, Zofia Daszyńska-Golińska: o nurt reformistyczny $w$ polityce społecznej (Poznań, 2004), 131.
} 
these countries. She penned a number of texts on female, child and youth employment, changing forms of family life, and situation of the unemployed. ${ }^{25}$

Many of the Ministry's female employees collaborated with the Social Economics Institute (Instytut Gospodarstwa Spotecznego, IGS). Founded in 1920, the IGS, run by Ludwik Krzywicki, ${ }^{26}$ established itself as a valued scientific and social institution pursuing economic and sociological research. Its members were ideologically inclined to socialism. Contributions from educated women, whose academic background and record with the Ministry of Labour and Social Care made them well-versed in theoretical and practical social problems of post-war Poland, were irreplaceable for the development of research work. The other organisation that offered a space for a number of the Ministry's female workers to perform scientific work was the Polish Society for Social Policy (PTPS), since 1924 - an organisation set up by a group of the most outstanding social policy experts. One among them was Zofia Daszyńska-Golińska, who until her death in 1934 was Deputy Chairwoman of the PTPS and one of the main organisers of its activities. ${ }^{27}$ Also, Bornstein-Łychowska and Lipszyc-Balsigerowa were among the most proactive PTPS members. The presence of these and other members, excellent specialists in social policy, contributed to the fulfilment of the organisation's statutory objectives: an institution of academic and popularisation work, PTPS addressed the problems of living and working conditions of people, social insurance, the situation of emigrants, the functioning of local government, unemployment in urban and rural areas, and more. Daszyńska-Golińska represented the organisation at international congresses on social policy, including the one held in 1924 in Prague and those of 1925 and 1927 in Berlin. ${ }^{28}$ Taking part in foreign congresses, the scholar

${ }^{25}$ Halina Krahelska, tódzki przemyst wtókienniczy wobec ustawodawstwa pracy (Warszawa, 1927); eadem, Praca dzieci i mtodocianych $w$ Polsce (Warszawa, 1928); eadem, Praca mtodocianych a opieka spoteczna (Warszawa, 1930); eadem, Praca kobiet w przemyśle wspótczesnym (Warszawa, 1932); Halina Krahelska and Stefan Pruss, Życie bezrobotnych: badania ankietowe (Warszawa, 1933).

${ }^{26}$ Ludwik Krzywicki (1859-1941) was a sociologist, economist, ethnologist, social activist and educationalist, organiser and promoter of science. He was a professor with the University of Warsaw and with the Free Polish University; he run the Social Economics Institute and was the first chairman of the Polish Sociological Society.

27 http://ptps.org.pl/historia [Accessed: 10 Dec. 2017].

${ }^{28}$ Renata Owadowska, Zofia Daszyńska-Golińska, 137. 
resorted to the well-tested strategy: as she could not deliver lectures at a university, she presented the outcomes of her research at scientific conventions, conferences, or congresses. Bornstein-Łychowska and Lipszyc-Balsigerowa had their important dissertations in aspects of social policy published under the aegis of the PTPS. ${ }^{29}$ BornsteinŁychowska moreover edited the organisation's periodical Wiadomości Spoteczne, which dealt with the condition and the needs of social policy in Poland and abroad.

Under the auspices of the Ministries as well as the IGS, PTPS, and other social organisations, female intellectuals who had no opportunity to pursue a 'classical' academic career conducted empirical studies and published their texts which fully met the scientific criteria, reviewed foreign- and Polish-language studies. For instance, after her studies with the Free Polish University in 1926-8 where she attended a seminar run by Zofia Daszyńska-Golińska, Anna Minkowska collaborated with the IGS, conducting studies in the living conditions of unemployed families, the situation of children and youth within such families, the shaping of family bonds and the psychological consequences of joblessness. ${ }^{30}$ Bornstein-Łychowska published several essays on the situation of working-class people and a dissertation on labour protection; ${ }^{31}$ she authored a monograph concerning the social policies employed by Poland in the first decade after the country regained independence (a French and English edition were published as well). ${ }^{32}$ Lipszyc-Balsigerowa's study on the consequences of unemployment, based on her interviews with those made jobless, encompassing a total of 200 Warsaw families, was recognised as a model elaboration for empirical research in this particular area. ${ }^{33}$ The study confirmed its

${ }^{29}$ Melania Bornstein-Łychowska, Międzynarodowa Organizacja Pracy (Warszawa, 1928); Maria Balsigerowa, Społeczne skutki bezrobocia wśród fizycznych robotników przemystowych m.st. Warszawy w świetle ankiety roku 1931/1932 (Warszawa, 1933).

30 Anna Minkowska, Rodzina bezrobotna na podstawie ankiety 1932 r. (Warszawa, 1935).

${ }^{31}$ Melania Bornstein-Łychowska, Płace $i$ ruchy robotnicze $w$ Warszawie $w$ roku 1917 i 18 na tle czynności niemieckiej komisji ptac (Warszawa, 1919); eadem, Co daje Rzeczpospolita Polska i rzad polski robotnikom w Polsce? ([place of edition not specified], 1920); eadem, Ochrona pracy pracowników handlowych i przemystowych (Warszawa, 1925).

32 Eadem, Dziesieć lat polityki spotecznej państwa polskiego 1918-1928 (Warszawa, 1928).

${ }^{33}$ Maria Lipszyc-Balsigerowa, Spoteczne skutki bezrobocia wśród fizycznych pracowników przemystowych $\mathrm{m}$. st. Warszawy w świetle ankiety roku 1931/32 (Warszawa, 1932). 
author's excellent qualification as a field-study researcher. ${ }^{34}$ An efficient official and expert, Lipszyc-Balsigerowa was moreover active with the cooperative movement, as an associate with the Warsaw Housing Cooperative (WSM) in the district of Żoliborz. ${ }^{35}$

A considerable number of female tertiary graduates who studied in the late years of the nineteenth and in the first decades of the twentieth century took up work with education and educational institutions. Some women deliberately followed such a career path, approaching their studies as an occasion to broaden their knowledge and work out competencies indispensable to work as teachers. But it was not infrequent that graduates who during and shortly after completion of their studies made efforts to embark on a strictly academic work eventually had to become education workers as the available source of income. Some of them managed to combine the job with journalistic or scholarly activity. Many women proved to be excellent specialists in education; the experiences gained through their practice as teachers inspired them to elaborate their own methodological concepts, elaborate didactic measures and/or syllabuses across the levels of education. The most talented among them, and most fond of pedagogical theory, worked out theoretical concepts of their own, integrated into various currents of educational sciences. While the number of female teachers and popularisers of knowledge on education who authored scholarly studies was quite high, not many of these texts had a broader reach in academic circles. Studies of this sort were mostly read by practitioners. Their authors' numerous teaching obligations, often combined with social activities, did not help deepen the scientific reflection. Teachers' organisations did not contribute to a fulfilment of scholarly ambitions, focusing instead on the fulfilment of teaching and educational tasks (and basically expecting the same from the teachers), often promoting the work performed for the education system and educational institutions in terms of mission and commitment. ${ }^{36}$ The female pedagogues' or teachers' ambitions exceeding such confines not always met with favourable response in, or outside, the professional circle.

Favourable conditions for independent activities in the field of organisation of the school system and development of theoretical

${ }^{34}$ Włodzimierz Wincławski, Stownik biograficzny, i (Toruń, 2001), 23.

${ }^{35}$ Zofia Noworól, 'Maria Lipszyc-Balsigerowa', 223-4.

${ }^{36}$ Dobrochna Kałwa, Kobieta aktywna w Polsce międzywojennej. Dylematy środowisk kobiecych (Kraków, 2001), 58-69. 
foundations for teaching were provided, in turn, by teacher training institutions, which formed an intermediate level between teachers' seminaries and tertiary schools. An evident example is the activities of Adela Stefanowicz, who in 1921 took up a job with the State Institute of Special Pedagogy in Warsaw. Before then, as a tertiary graduate, she was an educational and foster care worker, dealing with underage criminals and mentally disabled children. After she pronounced her religious vows in 1928, she practiced educational/foster care with orphaned and neglected children, and developed her own educational system. She was appointed Chairwoman with the Catholic Educational Union in 1938 and set up a teacher seminary for girls at Łosiówka near Wilno. After the Second World War, she established, together with the Rev. Józef Wojtukiewicz, a Catholic Institute tasked with teaching religion instructors and Catholic educators; with this institution, she run classes in pedagogy, psychology, sociology, and religious education. ${ }^{37}$

After she completed her doctoral degree in Philosophy in Switzerland, Ludwika Jeleńska (1885-1961) got employed as a teacher with the State Teachers' Seminary in Grodno, lectured at holiday courses for teachers, and had in parallel several studies published on methodology of teaching and developmental psychology. ${ }^{38}$ Likewise, Wanda Dzierzbicka (1882-1977), Maria Grzywak-Kaczyńska (1886-1979), Natalia Han-Ilgiewicz (1895-1978), Stefania Marciszewska-Posadzkowa (1874-1955), Stefania Sempołowska (1870-1944), Zofia Żukiewiczowa (1881-1956), and Barbara Żulińska (1881-1962) all pursued a combination of diverse forms of activity - as teachers, organisers, scholars, journalists, and social activists. ${ }^{39}$

The examples of women who created new, or novel, pedagogical concepts outside the academic structures are numerous: suffice it to recall Irena Pannenkowa's works dealing with pedagogical issues, including problems of patriotic upbringing..$^{40}$ In fact, most of the female teachers and publicists incidentally published texts of significance for

${ }^{37}$ Swastek, 'Adela Stefanowicz'.

${ }^{38}$ Ludwika Jeleńska, Metodyka pierwszych lat nauczania (Warszawa, 1927); eadem, Sztuka wychowania (Warszawa, 1930); eadem, Wzrastanie psychiczne dziecka (Poznań, 1939).

${ }^{39}$ Bobrowska-Nowak and Drynda (eds.), Stownik.

${ }^{40}$ Irena Pannenkowa, Nowe myśli o wychowaniu: reforma szkolna (Warszawa, 1925); eadem, Nasze zadania wychowawcze (Warszawa, 1929); eadem, Wychowanie państwowe czy narodowe?(Warszawa, 1930). 
development of science; they mostly focused on constructing original systems of education, care and upbringing, proposed methodological solutions, and vocational education of teachers and educators. Methodology was predominant in this appreciable writing output; no deeper theoretical reflection offered in these works was their major drawback.

Professional career prevented the fulfilment of scholarly ambitions of even those women whose academic career seemed very promising during their university education. This is excellently illustrated by the case of Ewelina Wróblewska: once she became a school system worker, she would undertake no further activities in the realm of science - although, apart from secondary schools, she worked with Cracow's 'Adam Mickiewicz' People's University and the State Courses for Teachers. ${ }^{41}$ She strove to exceed the traditional confines of her profession by editing source texts for purposes of teaching history; also, she wrote a biography of Józefa Rodziewiczówna. ${ }^{42}$

Improvement of the professional situation of educated women was enabled, to some extent, by female social activism, which set as a purpose for itself to enable such women to participate in public life in a manner adequate to their education and qualifications, to broaden the prospects for their university-level education and academic activities. ${ }^{43}$ Organisations supporting women in fulfilment of their aspirations - educational academic, professional, and political - were set up by female university graduates. Of special importance in this respect was the Polish Association of Tertiary-Educated Women, established in $1926 .{ }^{44}$

${ }^{41}$ Wincławski, Stownik biograficzny, iv, 190.

42 Józefa Rodziewiczówna, penname 'Wanda' (1867-1931), was a teacher and socialist activist; cf. Ewelina Wróblewska, Józefa Rodziewiczówna (Wanda), bojownica o wolność (Kraków, 1933).

${ }^{43}$ Iwona Dadej, “"Do czego dążymy?” Niemieckie i polskie akademiczki i ich strategie walki o uznanie w epoce dwudziestolecia międzywojennego. Nowy porządek płci w nauce dzięki ruchowi społecznemu?', in Izabela Desperak and Inga Kuźma (eds.), Kobiety niepokorne: reformatorki, buntowniczki, rewolucjonistki: herstorie (Łódź, 2017), 82-5.

${ }^{44}$ Jan Bełcikowski, Polskie Kobiece Stowarzyszenia i Związki Wspótpracy Międzynarodowej Kobiet (Warszawa, 1939), 103-112; Kałwa, Kobieta aktywna, 147-8; Maria Wierzbicka, 'Polskie Stowarzyszenie Kobiet z Wyższym Wykształceniem (1926-1948)', in Agnieszka Janiak-Jasińska, Katarzyna Sierakowska, and Andrzej Szwarc (eds.), Działaczki społeczne, feministki, obywatelki...: samoorganizowanie się kobiet na ziemiach polskich po 1918 roku (na tle porównawczym), i (Warszawa, 2009), 153-76; Owadowska, Zofia Daszyńska-Golińska, 137. 
The activities of female organisations were all the more important that mechanisms of exclusion were visible not only within universities but also in a number of academic associations which were reluctant to include women; Poland's most prestigious society of pedagogues is quite exemplary in this respect. The founding meeting of the Academic Pedagogical Association held on 2 December 1928 was attended by thirteen male founding members plus one woman, Ms. Grzegorzewska. ${ }^{45}$ The organisation was primarily founded by professors working at universities; some of them dealt with issues of pedagogy, whilst others specialised in psychology. The admission was conditioned by having a record of high-standard publications in pedagogy; these requirements, posed by the professors, were set very high. Each candidate had to be proposed to the Board by three members, which was followed by a secret voting; acceptance as a member required approval from twothirds of the attending members. As Grzegorz Michalski ascertains, "the terms of affiliation with the Academic Pedagogical Association were extremely strict, and thus the organisation grew in members very slowly". ${ }^{46}$ The institution was, in effect, pretty hermetic and women who functioned outside universities had no easy access to it. While women were generally perceived as predestined to act in the spheres of education, care, and upbringing, this was limited to practice. In the strictly academic organisations, educational or upbringing-related disciplines were seen as a domain of males, as was the case with universities.

IV

FEMALE ACADEMICIANS IN THE INSTITUTES AND AT THE FREE POLISH UNIVERSITY

The mechanisms of exclusion from the university space of women dealing on a scholarly basis with educational and foster care issues,

${ }^{45}$ Operating under the auspices of the Jagiellonian University, the Association consisted of scholars dealing with pedagogical issues and representing various academic centres all over the country. Apart from M. Grzegorzewska, among the founding members were: Władysław Heinrich, Stanisław Kot, Zygmunt Mysłakowski, Mieczysław Ziemnowicz, Stanisław Łempicki, Kazimierz Twardowski, Stefan Błachowski, Ludwik Jaxa-Bykowski, Eugeniusz Piasecki, Stefan Szuman, Florian Znaniecki, Stefan Baley, Bogdan Nawroczyński. Cf. Grzegorz Michalski, Zygmunt Mysłakowski (1890-1971): dziatalność i twórczość pedagogiczna (Łódź, 1994), 44.

46 Ibidem. 
pedagogical-and-psychological as well as social policy problems, regardless of their academic achievements, are clearly perceptible in the biographies of a number of outstanding Polish women intellectuals. None of the women specialising in any of the enumerated disciplines could pursue the 'classical' academic career path before 1945. Instead, every one of them experienced the exclusivism of the university which remained a male-dominated area. This was true not only with the beginners but also with scholars enjoying international renown and fame.

The difficulties women had to struggle with when seeking employment in the masculinised academic circle became particularly evident when Józefa Joteyko applied for a chair with the University of Warsaw as she returned to Poland in 1919. Her qualifications as a research scholar were unquestionable: she was an excellent expert in experimental psychology, had a number of articles published with journals of renown; her practical research experience gained at the universities in France and Belgium was enormous. Her career record included employment, since 1898, with the Solvay Physiological Institute; for several years, she worker with, and managed, the Psychophysical Laboratory at the Brussels University. The said University, as well as teacher training seminaries strove to have her lecture in educational and experimental psychology. She formed a Paedological seminary, which she later transformed into an International Paedological Faculty. Joteyko was the first foreign woman to be invited, in 1915, to deliver a series of lectures at the Collège de France in Paris. ${ }^{47}$ She moreover lectured at the Sorbonne and at the Lyon University. She was a member of many academic organisations and chaired the Belgian Neurological Society; she was awarded several prizes, including the Institut de France award (four times), the Society for Medical and Natural Sciences of Brussels award (twice), the Prix Desmath (in 1900), Prix Dieudonné (1901), and Grand Prix Saintour awarded by the Collège de France. She was given a Gold Medal by the French Society of Chemists. ${ }^{48}$

In spite of Joteyko's excellent position in international academia, the independent Poland never offered her a professorship with any of its state-owned universities. Instead, she found a job with the Pedagogical Institute in Warsaw, which was dissolved in 1926; in parallel,

${ }^{47}$ Otton Lipkowski, Józefa Joteyko: życie i działalność (Warszawa, 1968).

${ }^{48}$ Bobrowska-Nowak and Drynda (eds.), Stownik, 81. 
she lectured at the Institute of Special Pedagogy, which gave her an opportunity to teach classes, but not to do research. ${ }^{49}$ Grzegorzewska wrote that Joteyko was agonised by the "impossibility of developing her scientific activities any broader; deprived of a laboratory ... she pursues her activity in a situation that is awkward indeed, with so many honours and distinctions awarded abroad - there's no institute to employ her in her own country". ${ }^{50}$ In spite of the tough conditions, Joteyko committed herself to the building of a psychological milieu in Poland; making use of her Western experiences, she set up journals and societies, co-founded the Polish Psychotechnical Society. She established and was the editor of the quarterly Polskie Archiwum Psychologii [Polish Archives of Psychology]. ${ }^{51}$

In her struggle for regular employment with the Academia, Joteyko received help and support from Maria Grzegorzewska, her former student and then associate. Grzegorzewska was a no less excellently educated woman; holding a doctorate and having gained practical experience in a Paris school for mentally retarded children, she returned to Poland after the war ended, to help build a system of education, care, and upbringing. Her first employment at home was with the Ministry of Religious Confessions and Public Enlightenment, where she dealt with affairs of special education, establishing schools and care institutions, and organising a seminar course for teachers. The latter was transformed by Grzegorzewska, in 1922, into the State Institute of Special Pedagogy; she took charge of the Institute and worked there for the rest of her life. In 1930, Grzegorzewska established a State Institute of Teachers, which she run until she was summarily dismissed in 1935 due to her alleged political (anti-Sanacja) sympathies. ${ }^{52}$ In a letter to her friend Stefania Chmielakówna of 29 April 1935, she remarked: 'Stefuś, you probably know I have been dismissed by Mr. Minister ... he even would not allow me to complete the school year. He com-

49 Stanisław Sedlaczek, Józefa Jotejko (Warszawa, 1928), 5.

50 Maria Grzegorzewska, 'Po zgonie prof. dr. Józefy Jotejko', Ruch Pedagogiczny, v (1928), 135-6.

${ }^{51}$ Daria Domarańczyk, 'Czy kobiety nauki to kobiety sukcesu? Polki i ich dokonania w pedagogice i psychologii na przełomie XIX i XX wieku', in Desperak and Kuźma (eds.), Kobiety niepokorne, 72-6.

${ }^{52}$ Karol Poznański, 'Co z koncepcji Marii Grzegorzewskiej zachowaliśmy w systemie kształcenia nauczycieli?’, in Józefa Bałachowicz (ed.), Dziecko w koncepcjach pedagogicznych Marii Grzegorzewskiej i Janusza Korczaka (Warszawa, 2012), 16-7. 
municated to me on 26 April that from 1 May Mr. K[arol] Makuch will be Director there; end of the story. This is a painful thing for me, not for a personal reason, but I feel so terribly sorry for the institution". ${ }^{53}$

Grzegorzewska regarded it critical that each of the institutions she was ever in charge of would enable methodological and didactic work along with research. The founder of the Polish school of special pedagogy, she elaborated her own, original method of teaching and educational work with disabled children. She authored a number of articles and books in this area of expertise, edited specialist periodicals (including the country's first specialist journal Szkoła Specjalna, set up by her), was member of Polish and international pedagogical societies, attended international congresses at home and abroad. ${ }^{54}$

Established in 1919, the Free Polish University (Wolna Wszechnica Polska, WWP) became an 'alternative Academy' for those (including women) who could find no job with any of the state-run universities. The WWP emerged out of the Society for Academic Courses (active since 1906), as a legalised form of the formerly operating 'Flying University'. ${ }^{55}$ Zofia Daszyńska-Golińska worked for the WWP for a long time (1919-34); her career as a scholar illustrated how considerable were the problems posed to female intellectuals willing to win an autonomous status confirmed by the postdoctoral degree of habilitated doctor. With all her tremendous and valuable accomplishments in science, Daszyńska came across reluctance from the professorial staff at the Jagiellonian University: not only would they not accept the female scholar's aspirations but they denied her leftist views. Tackling economic, demographic, or social issues in her writings, she would often express different evaluations of the investigated problems than her male counterparts did. ${ }^{56}$ The dissonances occurring between Daszyńska and the intellectuals of Galician background,

53 Ibidem.

${ }^{54}$ Marian Balcerek, 'Szkolnictwo specjalne i pedagogika specjalna w pierwszej połowie XX wieku', in Stanisław Mauersberg (ed.), Dzieje szkolnictwa i pedagogiki specjalnej (Warszawa, 1990), 216-18.

55 Zofia Skubała-Tokarska, Społeczna rola Wolnej Wszechnicy Polskiej (Wrocław, 1967).

${ }^{56}$ For more on Daszyńska-Golińska's scholarly and journalistic activities, see Aneta Bołdyrew, 'Próba popularyzacji zachodnioeuropejskich teorii i wzorców kulturowych w piśmiennictwie naukowym i publicystyce Zofii Daszyńskiej-Golińskiej’, in Tomasz Pudłocki and Katarzyna Sierakowska (eds.), Aktywność publiczna kobiet na ziemiach polskich. Wybrane zagadnienia (Warszawa, 2013), 109-25. 
and the conservative milieu's reluctance toward the research she did, turned her efforts to proceed the conferment of the habilitation degree on her into a fiasco: in 1906, the habilitation committee turned her application down by a majority of vote. ${ }^{57}$ As Helena Radlińska wrote in her obituary of Daszyńska: "The relations prevailing at that time hindered her dreamt-of university activity, arousing regret in Daszyńska that she had not got habilitated in Germany". ${ }^{58}$ As Daszyńska recollected, "I once submitted myself for a habilitation with the Jagiellonian University but was refused, the reason they gave being that my works had not been outstandingly marked in the European science. In turn, my relationships with the Cracow professors were markedly estranged with every new book I had published. When still in Warsaw, in the conservative circles, I was spoken of as a radical" ${ }^{59}$ Daszyńska would not try to obtain a habilitation degree again, albeit she had a number of valued and innovative studies to her credit, which would have fully legitimated such strivings. As it seems, the scholar consciously quit the idea to ever more submit herself to the procedures created by the masculinised academic community. She sought a confirmation of her individual value and autonomy with other areas of the scientific world. Considered a persona non grata at Jagiellonian University, she cooperated with the 'Adam Mickiewicz' People's University in Cracow and with other social institutions of education. In spite of remaining outside the academic structures, Daszyńska carried out multiple field research projects. Her employment with WWP's Faculty of Political and Social Sciences enabled her to continue her scientific activity, though her activity with scientific and social societies (including female organisations) was quite of relevance in determining a strategy for building her position in science. Nonetheless, within the confines of the Free University she likewise had an opportunity to associate with outstanding scholars. To an extent, this meant that she followed up her earlier scientific work: enough to remind that Daszyńska's acquaintance and close cooperation with Radlińska had developed in Cracow before the First World War, at the People's University.

57 The Jagiellonian University Archive, class. no. WF II 121.

${ }^{58}$ Helena Radlińska, 'Śp. Prof. Zofja Daszyńska-Golińska', Ruch Prawniczy, Ekonomiczny $i$ Socjologiczny, i (1934), 574.

${ }^{59}$ Zofia Daszyńska-Golińska, Notatki autobiograficzne (Kraków, 1932), 12. 
The development of the WWP as an efficient academic institution was contributed to a high degree by Radlińska: this scholar and education activist, who was a leader in the construction of theoretical foundations of knowledge in social and pedagogical sciences, organisation of scientific teamwork, establishment of scientific and education institutions, and representation of Polish science in the international arena. She joined the WWP staff in 1922, and was granted a habilitation in 1925 based on a study on Stanisław Staszic as a social activist. In 1936, the ministerial jury approved her postdoctoral degree and granted her a full professorship. ${ }^{60} \mathrm{Her}$ choice of historical and education-related issues as the topic for her habilitation thesis was motivated by her education background acquired at the Jagiellonian University; in fact, aspects of the history of education, upbringing, and history of social work were close to Radlińska till her latest days. There was a pragmatic incentive behind it, too: in her own words, "one had to prove his, or her, background in a discipline already regarded as scientific and arousing no doubts in the professorial circle. My choice was social history, within whose perimeter the history of social work was containable". ${ }^{61}$

In parallel, ever since her studies she developed her interest in social work, school and off-school education, and adult education. As part of the Free University, she founded in 1925 a Social and Education Work Study. Thus, the year 1925 was a breakthrough moment in the academic career of Radlińska, then a forty-six-year-old woman: not only did she get her postdoctoral degree but also set up the Study, where she pursued her research and teaching work. While a WWP worker, she penned a number of scholarly studies forming part of her abounding output, numbering some 500 items. Radlińska is considered to have founded the Polish school of social pedagogy - a discipline whose underlying assumption is that actions taken to 'transform the social environment with use of human powers' are fundamental. ${ }^{62}$ She has remarkably contributed to the theory of social work, and dealt also with historical, sociological, and bibliographical issues.

${ }^{60}$ Jarosław Kita and Stefan Pytlas, W stużbie nauki: profesorowie Uniwersytetu Łódzkiego w latach 1945-2004: pro memoria (Łódź, 2005), 343.

${ }^{61}$ Helena Radlińska, 'Listy o nauczaniu i pracy badawczej', in eadem, $Z$ dziejów pracy społecznej i oświatowej, ed. Wanda Wyrobkowa-Pawłowska (Wrocław, 1964), 439.

${ }^{62}$ Irena Lepalczyk, Helena Radlińska: życie i twórczość (Toruń, 2002), 7. 
She considered 'referring to the related sciences' necessary, ${ }^{63}$ to the extent such sciences may help build theoretical concepts and set the strategies for practical action. ${ }^{64}$ Acting as Deputy Dean, and member of the University's Senate, reinforced her position with the WWP. Actually, this was a rather incidental case of a woman wielding power within the Academia space; the character of this particular University fostered the opportunity for this female academic to hold high-level executive functions. Agata Zysiak's remarks in this respect are pretty apt: she describes the WWP as a tertiary school of marginal import in terms of prestige, one that employed those who "suited the academic field in the Interbellum [1918-39] the least, proving overtly liberal or Left-oriented, opposing anti-Semitic excesses and feudal customs". 65 Functioning within such realities, Radlińska elaborated numerous scenarios that allowed her to form a model of academic activity of her own.

$\mathrm{V}$

HELENA RADLIŃSKA'S STRATEGIES FOR ACADEMIC AND TEACHING ACTIVITY

The elaboration of her own strategies for scholarly and organisational actions enabled Radlińska to build a new discipline - namely, social pedagogy. An important factor that fostered the development of her research was a network of cooperation with West European scholars and educationalists she had built. She was helped establish the first contacts outside Poland "by the academic authority and extensive acquaintances of Józefa Joteyko". ${ }^{66}$ Helena emphasised Józefa's hospitality, kindliness, and solidarity with her young female compatriots who were willing to develop their scientific aspirations. Józefa tried to build around herself a female intellectual circle. Helena was one of the many women attracted by Józefa: it can be presumed that the latter saw in female solidarity and in support of her younger colleagues an opportunity for breaking the male domination in the academia.

The strategy employed by Radlińska to help her build a position in the academia consisted in becoming part of transnational scientific

${ }^{63}$ Radlińska, 'Listy o nauczaniu', 444.

${ }^{64}$ Wincławski, Stownik biograficzny socjologii polskiej, iii (Toruń, 2007), 214.

${ }^{65}$ Agata Zysiak, Punkty za pochodzenie. Powojenna modernizacja $i$ uniwersytet w robotniczym mieście (Kraków, 2016), 229.

${ }^{66}$ Radlińska, 'Listy o nauczaniu', 408. 
activities through participation in international conventions and congresses and through development of very broad contacts with West European educational care institutions which researched into the issues that were mostly not covered in Poland at the time. Since the early 1920s, Radlińska was an active member of transnational organisations dealing with problems of education and upbringing; one such important organisation was the association called International Moral Education Congresses (IMEC), established in 1908 in London and later on, in 1938, merged with the New Education Fellowship. These organisations propagated fraternity, tolerance, coeducation, citizenship (or civic) education and self-government; they promoted supranational cooperation between scholars, education activists, and educators. ${ }^{67}$ Radlińska fully personally supported the organisation's leading pacifistic idea, counteracting conflicts, hatred, and xenophobia. She participated IMEC conferences in 1922 in Geneva and in 1930 in Paris. At the former, she delivered a lecture on the importance of teaching history for peace building, in which she emphasised that history is supposed to popularise a sense of 'all-human solidarity'; she touched upon similar issues at numerous other meetings of European scholars and educators. As a member of IMEC's Executive Department, Radlińska co-organised a congress held in Cracow in 1934, which attracted the most outstanding representatives of European educational and education-related institutions, thanks also to her involvement. ${ }^{68}$

As part of the New Education Fellowship, Radlinska contributed to the formation of the Polish Section, collaborating to this end with Maria Grzegorzewska, Halina Kuropatwińska, Jadwiga Michałowska, Anna Oderfeldówna, and Maria Sokalowa. ${ }^{69}$ She attended the League's conferences in Montreux in 1924, in Locarno in 1927, in Helingör/ Elsinör in 1929, and in Nice in 1932. When in 1929 the Fellowship's Central Board got established, with its seat in London, Radlińska represented the Polish Section within it. The Section's, and Radlińska's own, achievement was having several eminent European scholars invited to the Universal National Exhibition in Poznań (on this occasion, Édouard Claparède, Jean Piaget, Daniel Bovet, and Adolphe Ferrière were hosted,

67 'Liga Nowego Wychowania', Przeglad Pedagogiczny, xxi (1931), 463.

${ }^{68}$ Wiesław Theiss, 'Udział Heleny Radlińskiej w europejskim ruchu społeczno-pedagogicznym (1918-1939)', Society Register, i (2017), 157.

${ }^{69}$ Radlińska, 'Listy o nauczaniu', 422. 
among others). Another such achievement was the holding in 1931 in Warsaw of the First Slavonic Pegagogical Congress. ${ }^{70}$

Radlińska was no less active with the Union of International Conferences on Adult Education, which popularised education of adults and egalitarisation in access to culture. When a Polish Republic's Group of the World Association for Adult Education was formed in 1927, Radlińska acted as Deputy President. She joined the organisation's conventions - in 1922 in Cambridge, and in 1932 in Durbuy-surOurthe, Belgium. Since 1926 she represented Poland with the Executive Committee of the International Social Service Conference; a series of institutions emerged in several countries under this organisation's auspices. In 1926, Radlińska participated in a Paris convention of social work school headmasters, and presented there the assumptions, objectives, and achievements of the Social and Education Work Study she had formed. She took part in a number of conventions of the International Social Service Conference, presenting practical and theoretical aspects of social work, and focusing on terminological issues, the discipline's research fields, and the importance of professional instruction of social workers. ${ }^{71}$

Taking part in the works of supranational organisations, Radlińska was a proactive participant in the discussions on projects of their further activities and significance of international cooperation. She contributed to development strategies for international educationoriented and upbringing organisations. She initiated and developed contacts with scientists and researchers, with educational institutions across Europe; this achievement was particularly important given the aggravation of fascist trends. ${ }^{72}$ She found the democratic rules prevailing during the conventions and congresses close to her, with "the sense of fellowship embracing all those attending, from a nursery-school teacher to a university professor, and contributing to simplicity in immediately sharing whatever was considered new, or the best". ${ }^{73}$ She particularly cared about building a mood of collegiality and cooperation, and about developing a network of support in scientific and educational activities. What is more, international contacts offered an opportunity

70 Theiss, 'Udział Heleny Radlińskiej', 158.

${ }^{71}$ Ibidem, 159-60.

${ }^{72}$ Radlińska, 'Listy o nauczaniu', 415-16.

${ }^{73}$ Ibidem, 414. 
for Polish specialists to present their achievements in social work and theory of social pedagogy, social work, and social pedagogy theory; the latter was authored by Radlińska, who was recognised in Europe as an expert in the field already before the Second World War.

Radlińska sought original solutions also in institutional activities and as part of university-level teaching. Founding the Social and Education Work Study's curriculum in cruda radice, setting its assumptions, objectives, and forms of activity, she was driven by her own concepts and convictions; she moreover used to this end the experiences she had gained during her 1924 trip to centres of social and education work in Germany, Switzerland, Belgium, and Denmark. Radlińska's conviction about the fundamental importance of supranational cooperation and exchange of experience caused that she perceived the organisation of such trips for her associates and students as a priority for herself. In 1928, at a convention of the International Social Service Conference in Paris, the Polish delegation, numbering a hundred members, included a group of students who, looked after by Radlińska, visited a number of social and educational facilities and establishments in Czechoslovakia, Austria, Switzerland, and Belgium. ${ }^{74}$

Radlińska attached much attention to integration of those students whose background encompassed all social milieus, and who differed in age, worldview, life experience, and political involvement. ${ }^{75}$ She cared about building close relationships within the circle of assistant lecturers and assistant professors. In the introduction to a monograph co-authored by the attendees of a seminar she conducted, she wrote that the word 'we'/'us' used in the discussion of the research outcome has nothing in common with the customary pluralis maiestaticus; instead, what it denotes is 'we, the team'. Team-work and team effort was the most important feature in educating the researchers at the Study". ${ }^{76}$ Teamwork strategy, building among the students and associates of an ethos of liaison and interaction was a planned and deliberate action on the part of Radlińska, who knew how to create a cohesive team in the spirit of companionship. Characteristic of the Study's climate was a great care about organising the students' effort based upon

${ }^{74}$ Theiss, 'Udział Heleny Radlińskiej', 161.

${ }^{75}$ Jan Hulewicz, 'Wstęp - Helena Radlińska', in Helena Radlińska, Z dziejów pracy spotecznej, XV.

${ }^{76}$ Radlińska, 'Listy o nauczaniu', 450. 
individualisation and frequent direct consultation. ${ }^{77}$ In terms of modern psychology, Radlińska preferred a transformational style of leading a team of associates and students, and assumed the role of a guide to support their autonomy and participatoriness. ${ }^{78}$ Defying the patriarchal model in which a tertiary school worker functioned in her time, she consciously remodelled the academic habitus by enlarging the array of skills and competencies, which she considered valuable as determinants of perception and conceptualisation of the world.

\section{VI \\ (UN)APPRECIATED, (UN)REMEMBERED}

Women experts in educational sciences and social policy theories, whose contribution to the production of knowledge and science was essential, encountered numerous adversities, within as well as outside the Academia. The brief biographies of the women in question, who desired to fulfil their scientific passions, show how reluctance and arbitrariness of the male-dominated academic world where gender was of critical importance to career opportunities affected them. This was not limited to opportunities of promotion in science and of finding employment with a university: women had difficulties with recognition and appreciation of their scientific output. To give an example, in his doctoral thesis on children and youth of Łódź,

77 "The transition from the University of Warsaw to the Study was for me an entry into a world that was thoroughly new. There [i.e. at the University], impersonality of a vast higher school, the responsibility for the studies and how they are organised to the student's own maturity. ... The climate at the seminars and course workshops, which ought to have created more animated contacts, was conditional upon the professor [in charge]. There were so many amongst them who were, regrettably, scientists of diverse measure, who treated their pedagogical work as a secondary necessity. ... Here, at the Study, there is trust, but there is control too: not some police-like control but through the organisation of the whole thing, which directs everyone to his assumed responsibilities and tasks, of which [sic] one needed to exhibit. The time is filled to the brim since the beginning of the school year. Lectures, of which there were as many as at the University and which were attended in a most regular fashion, seminars, site-visits, practices, publicly delivered papers and, oftentimes, individual examination".: Anna Bogusławska, 'Szkoła jutrzejsza i jej kierowniczka', Zeszyty Historyczne, xix (1971), 174.

${ }^{78}$ Marek Młodożeniec and Anna Knapińska, 'Czy nauka wciąż ma męską płeć? Udział kobiet w nauce', Nauka, ii (2013), 58-9. 
written at the Jagiellonian University's Pedagogical Seminar under Professor Zygmunt Mysłakowski, Tadeusz Nowacki referred to none of the studies by a female author. It nonetheless seems that while ignoring their conclusions Nowacki found the empirical studies and theoretical findings of female pedagogues and specialists in social policy theory valuable, be it for the purpose of comparative analysis. ${ }^{79}$ Obviously, there were many pedagogues and social policy theorists who appreciated and respect the valuable, not infrequently pioneering, articles and books written by female researchers, quoting and/ or reviewing them in scientific and trade journals. However, before 1939, such respect or appreciation was in most cases expressed by males who functioned far away from universities themselves, being workers of the WWP, IGS, or journal editorial boards.

The type of relationship prevalent between genders in the world of Academia contributed to patronisation of women with scientific aspirations; misogynistic comments on their intellectual potential were no rarity. Ludwik Krzywicki would nowise appreciate Daszyńska-Golińska, a talented and assiduous woman. As he wrote in his memoirs, "She travelled to the University of Zurich, and again I could hear there that jokes were made about her allegedly writing some dissertation of a statistical sort, dealing with the counting of cobblestones in the streets of Zurich. The jokes were merciless, ignoring overmuch Miss Zofia's talents, but rendered quite well the dryness of her mind, so to put it". ${ }^{80}$ For a change, Krzywicki did enormously appreciate the work of Radlińska, particularly, however, in the context of her involvement with the Study. He wrote with respect of her complete commitment to the institution, emphasising "an enormous amount of energy expended, and indefatigable perseverance in managing any once-commenced affair". ${ }^{81}$ He never referred, though, to the effects of Radlińska's research as such, focusing instead on her teaching and organisational activities and emphasising their social value, in the first place. It seems that there was a trend in Polish society to affirm the research, teaching, and organisational involvement of female academicians which was considered greater than in the case of their

${ }^{79}$ Tadeusz Nowacki, Rozwój świadomości spotecznej u dzieci i młodzieży warstwy robotniczej Łodzi (Łódź, 1939).

${ }^{80}$ Ludwik Krzywicki, Wspomnienia, i (Warszawa, 1947), 264.

${ }^{81}$ Ibidem, iii (Warszawa, 1959), 388. 
male counterparts, which at times directly led to expecting that such women would assume the attitude of a 'strongwoman'.

Female intellectuals of Jewish descent who represented leftist views experienced a double marginalization. The social conservative press in the time of the Partitions as well as in the interwar period dispraised the 'freethinking' of female intellectuals (on a par with radical attitudes amongst their male peers), approaching their views as a threat to social order. Given the context, the activity of female progressive pedagogues was regarded as particularly deleterious, as they promulgated a change in the style of rearing girls and boys, coeducation, and introduction of sexual education in schools. The most aggressive criticism was uttered in the press that made use of anti-Semitic slogans; the Rola weekly repeatedly faulted the adherents (of either sex) of coeducation for intending to "graft, by sheer force, villainy and debauchery already at the school stage". ${ }^{82}$ Another argument for the anti-Semites was the fact that some women doing scientific work and active with feminist organisations were of Jewish origin. Ignorant texts published in the press tried to confound the activities of the female organisations they were members of. The Catholic daily Głos Mazowiecki recollected in July 1938 a congress of the Union of Female Civic Labour at which problems of education and upbringing were discussed, mentioned the attendees by name, describing them as Jewesses, communists; there was Radlińska too, "known for her free-thought beliefs". "The Catholic public opinion ought to bear this congress in mind and never again admit Jewesses to speak about women's affairs in Poland". ${ }^{83}$ Intellectuals tended to express their reluctance toward 'women radicals' female scientists of Jewish descent in veiled but decipherable terms. A 'different' ethnic background and worldview were the other factors of non-acceptance for women's labour in the reborn Poland as university lecturers.

Devaluing the women's achievements was due also to the ways in which they professed scholarship, sought for new research areas, strategies and perspectives, which in the case of the most eminent female intellectuals stemmed from transnational scientific contacts (among other drivers). Such contacts enabled these scholars to gain

82 'Na posterunku', Rola, 33 (1905), 506.

83 'Oto, dla czego na Kongresie Społecznym w Warszawie pominięto zupełnie znaczenie religii w wychowaniu', Gtos Mazowiecki, vii, 154 (1938), 2. 
much broader perspectives of vision of the issues researched into, which fostered a pluralistic attitude toward the theory and methodology of their own research. Characteristic to research conducted by many a female intellectual was their drawing knowledge from various disciplines, accepting strictly academic inspirations along with those from the field of educational and social practice, integrating theoretical references and models of practical action. The research, studies and elaborations were partly based on a praxeological approach, seeking to recognise the defined aspects of the reality under research whilst at the same time striving for its conscious and purposeful shaping.

Forced to work intensely within a competitive environment of academia and education, which was so tough for women, they would often address innovative issues, not yet recognised in Poland. Daszyńska-Golińska's research on the situation and life prospects of indigent and neglected youth and the juvenile labour legislation serve as a case in point.$^{84}$ Her studies written in the early years of the twentieth century paved the way open for further research in these areas; that Daszyńska can be recognised as a precursor of juventology (youth science), a discipline in its own right since Daszyńska's time, is not a commonly known fact, though. ${ }^{85} \mathrm{~A}$ number of female scholars had innovative ideas about how to conduct scientific research and what issues were worth analysing; thus, they developed research in marginalization, exclusion, or social compensation. As a hypothesis calling for further detailed research, it can be argued that a number of articles penned by female authors dealt with herein show the trend to heavily rely on sociological notions whilst partly reducing philosophical reflection, which is usually fairly broadly represented in studies authored by male authors. The areas of their scholarly penetration, the method of their pursuit - oftentimes different from

${ }^{84}$ Zofia Daszyńska-Golińska, 'Robotnicy młodociani w rzemiośle i rękodziełach w Krakowie', Czasopismo Prawnicze i Ekonomiczne, xiv (1913), 28-139; published also as a separate offprint. Eadem, Robotnicy młodociani w rzemiośle i rękodziełach w Krakowie: na podstawie wywiadów Uniwersytetu Ludowego im. Ad. Mickiewicza w Krakowie (Kraków, 1913).

${ }^{85}$ Research on the specificities of adolescence was pursued in the English-language cultural environment beginning with the monograph by Stanley G. Hall. In German-speaking countries, the first decades of the twentieth century saw an increase in scholarly interest in youth issues, Siegfried Bernfeld's research and publications made a remarkable contribution. 
research conducted by male academicians - aroused limited interest among some professors. As a result, the attainments of many women pedagogues, educational sociologists and experts in social policy, who are considered indisputable scientific authorities today, was severely unappreciated at the time it was emerging. Disfavouring of women was manifested in marginalization of the importance of their scientific texts, which had a bearing on the presence/absence of these scholars and scientists also in Polish educational historiography. ${ }^{86}$

Belittling the female researchers active in the field of educational sciences had to do with debasement of the very disciplines regarding education, upbringing/rearing, and care - the areas of social life that were traditionally ascribed to women. For a number of academicians, these issues were (once in a while) liable to underestimation, and afforded a secondary rank in the scientific space; consequently, the need for a professional academic formation of practitioners in these areas remained underestimated. Later on, the Second World War over, pedagogical studies were still often regarded as less valuable. Olga Czerniawska thus recollects the opinion of Professor Tadeusz Pasierbiński, who tried to discourage her from getting educated in this field: "Why should you go to these studies? There are ignoramuses there, and you've got your tertiary degree, just go do your doctorate, rather than bother with Pedagogics. You're a History graduate, and that's a genuine field, then you are prepared to do academic work". ${ }^{87}$

Some scholars who represented areas of knowledge regarded as 'classical' approached educational sciences and, partly, also social policy sciences not in terms of autonomous domains of knowledge but rather as a collection of reflections driving the practical activities of teachers, educators, and social workers. This made it easier to underrate the scientific renown of experts pursuing research and academic teaching in these fields, which was particularly true for women. When appraising the achievements of female scholars, their successes in organising new forms of educational system and popularisation of knowledge, not always appreciating their actual role in the development of the theoretical foundations, notional and conceptual apparatus, and

${ }^{86}$ See Bogdan Nawroczyński, Polska myśl pedagogiczna: jej główne linie rozwojowe, stan wspótczesny i cechy charakterystyczne (Lwów, 1938); Ryszard Wroczyński, Dzieje oświaty polskiej 1795-1945 (Warszawa, 1996).

${ }^{87}$ Kaja Kaźmierska, Katarzyna Waniek and Agata Zysiak, Opowiedzieć Uniwersytet. Łódź akademicka w biografiach wpisanych w losy Uniwersytetu Łódzkiego (Łódź, 2016), 114. 
methodology of science. This oftentimes led to putting those women scholars who built new (sub)disciplines in educational sciences on the same footing as educationalists and knowledge popularisers. With all due respect to the attainments of those latter, such equalisation must be deemed an illegitimate simplification and a form of marginalizing the importance of the female pedagogues' scientific output.

Our contemporary culture of memory tends at times to underrepresent the scientific activities of female intellectuals, including in respect of specified professional milieus. Commemorative activity manifests itself in actions taken to solidify and popularise knowledge on the women scholars who created new disciplines of knowledge; one such interesting initiative was the formation of a Maria Grzegorzewska Museum within the Warsaw-based Maria Grzegorzewska Academy of Special Education. Regrettably, a large portion of such projects have focused on presenting the merits, without deeply penetrating into the scientific biography of the intellectuals. As a result, details of education and academic promotions all too often tend to be neglected. What is more, erroneous details are sometimes given: with the said Museum, the Brussels seminary where Grzegorzewska completed her course, the institution once established by Józefa Joteyko, is misnamed. Mistaken or imprecise information is reproduced as no systematic research has been done on the scholars' biographies. Also some strictly academic studies quote erroneous data: the Polish Biographical Dictionary mistakenly ascribes the authorship of the book Rodzina bezrobotna... (cf. fn. 24), written by Anna Minkowska, the IGS contributor, to her historian namesake. ${ }^{88}$

In compiling biographies of female researchers or scholars, the attitudes of public-spiritedness, empathy, and protectiveness tend to be particularly emphasised, apart from their scholarly achievements; this seemingly comes, among others, from a strife to prepare biographical notes of such intellectuals in line with the ideas of 'natural' female characteristics and attributes. When writing about Radlińska, her associates and students stressed that she was a person of great sensitivity and kindness. ${ }^{89}$ She was called 'Grandma', and regarded as

${ }^{88}$ Helena Więckowska, 'Minkowska z Zandów Anna Jadwiga', [dictionary entry] in Rostworowski (ed.), Polski Stownik Biograficzny, xxi (1976), 300. Wincławski, Stownik biograficzny, ii, 329, gives the right information.

${ }^{89}$ Biblioteka Jagiellońska, Dział Rękopisów, Materiały Józefy Korpały, sygn. 556/14: O wptywie Heleny Radlińskiej na moją dziatalność zawodowa, dydaktyczna i naukowo- 
"direct in contacts, her way of being simple, a plausible person". ${ }^{90} \mathrm{Her}$ independence and self-creativity in setting the areas of scientific search, obstinacy and consistency in organising the academic structures, and her extensive international contacts were not as widely appreciated. In spite of concordant opinions regarding Radlińska's merits for the development of science, her interesting output kept at the University of Łódź's Manuscripts Section has not yet been investigated or inventoried. Scholarly papers or treatises use Radlińska's recollections of her private life to a very small extent, though she openly recounts her relationship with her parents, health problems, aspects of her marriage, financial issues, and her attitude toward religion. Opinions on the relationships at the seminars she run are reluctantly quoted if found contrary to those of most of the students. ${ }^{91}$ This has to do with a hagiographising approach to biographies of women scientists: a rather common phenomenon in scholarly and popular-science elaborations. ${ }^{92}$ As a matter of fact, this true also with respect to biographies of their male peers.

\section{VII \\ CONCLUSION}

The entry of women scholars doing research in pedagogical sciences and theory of social policy into the various areas of Poland's academic life in the first four decades of the twentieth century was a stage marked by democratisation of the Academia. It came as a challenge to the established cultural reluctance towards women who aspired for

-badawcza, 1r-5v; Tadeusz Szymański, 'Wspomnienia nauczyciela o studiach i pracy zawodowej', w Irena Lepalczyk and Beata Wasilewska (eds.), Helena Radlińska - portret pedagoga (rozprawy, wspomnienia, materiały) (Łódź, 1994), 141.

90 Teodora Mikołajewicz, 'Wychowywała do służby człowiekowi', in Lepalczyk and Wasilewska (eds.), Helena Radlińska, 114.

${ }^{91}$ Halina Wężyk-Widawska wrote, for instance, that she personally valued Radlińska high; yet, as she remarked, "honestly, however, and should this be of use in outlining her portrayal as a person and the type of influence she was exerting, I was offended by the climate of adoration around Mrs. Radlińska. This was something completely different than the cordial, or even friendly, relations that prevailed, at least, at the USB [i.e. Stefan Batory University in Wilno]". University of Łódź Library, Manuscripts Section, Helena Radlińska Archive (under development).

92 Iwona Dadej, “"Mittendrin statt nur dabei?” Niemieckie badania nad historią płci w nauce. Rekonesans', Rocznik Antropologii Historii, ii (2014), 186. 
scientific/academic autonomy and who were willing to become part of academic communities. The challenge was all the more difficult that it appeared in absence of any scientific policy of the state which would have supported the female intellectuals' work at the universities. The patriarchal approach towards women was overcome very slowly in 'tradition-oriented' universities - the institutions that transmitted the existing order, norms, standards and values in the world of science. Such exclusivism was opposed by those scientific milieus where women were represented to a higher degree.

The processes of inclusion into academic structures and hierarchies took place outside the prestigious Polish universities whereat chairs or institutes of pedagogy were set up (between 1918 and 1939, such units appeared at the universities of Warsaw, Cracow, Poznań, Lwów, Wilno, and at the Catholic University of Lublin; a Pedagogical Institute was formed in 1928 in Katowice, as an autonomous unit), all managed by men. The hermetic nature of the world of science, dominated as it was by the masculinised university community, was being broken down by women academicians working in teacher training institutions and the Free Polish University, and by women active with off-Academia structures - including the Social Economics Institute and the Polish Society for Social Policy. Among the varied practices and strategies usable in paving a place for women in the scientific environment, creation of formalised as well as informal communities supporting female intellectuals in their careers and research was of primary importance, along with participation in supranational organisations. Attending international congresses and conventions, contacts with scholars and educationalists across Europe favoured the recognition of the empowerment of Polish female intellectuals, thus compensating for the marginalization and reluctance from some of their male peers at home.

Women who pursued research with Institutes not established as full-fledged tertiary schools, or within the WWP, which was a private school, attained high positions there not only due to their research or teaching achievements but also owing to the executive functions they performed. Higher-level schools established with contribution of women posed an interesting alternative for the prestigious universities; their competitiveness was based, among other things, on an innovative approach toward the forms of student instruction. However, it did not change the educational model that functioned within the Academia 
and in the traditional scientific societies where the top hierarchical positions were reserved for males.

In spite of the basic differences in the selected scientific biographies summarised herein, the incentives that drove these women in their strife for intellectual development and scholarly and academic work, and for challenging the exclusivity of men in science, can be extrapolated on the entire gender group. The women in question wanted access to the profession of academician democratised. They formed an internally diverse group in terms of social background, ideology, political inclinations, intellectually, and so on. But they were united in their desire to fulfil their potential as professionals and scholars - or, more specifically, as experts, researchers, editors of industry magazines, organisers of academic life in the university environment and in social scientific societies.

trans. Tristan Korecki

\section{SELECTED BIBLIOGRAPHY}

Bełcikowski Jan, Polskie Kobiece Stowarzyszenia i Związki Wspótpracy Międzynarodowej Kobiet (Warszawa, 1939).

Bobrowska-Nowak Wanda and Drynda Danuta (eds.), Stownik pedagogów polskich (Katowice, 1998).

Bołdyrew Aneta, 'Próba popularyzacji zachodnioeuropejskich teorii i wzorców kulturowych w piśmiennictwie naukowym i publicystyce Zofii Daszyńskiej-Golińskiej', in Tomasz Pudłocki and Katarzyna Sierakowska (eds.), Aktywność publiczna kobiet na ziemiach polskich. Wybrane zagadnienia (Warszawa, 2013).

Dadej Iwona, “"Do czego dążymy?” Niemieckie i polskie akademiczki i ich strategie walki o uznanie w epoce dwudziestolecia międzywojennego. Nowy porządek płci w nauce dzięki ruchowi społecznemu?', in Izabela Desperak and Inga Kuźma (eds.), Kobiety niepokorne: reformatorki, buntowniczki, rewolucjonistki: herstorie (Łódź, 2017).

Dadej Iwona, “"Mittendrin statt nur dabei?” Niemieckie badania nad historią płci w nauce. Rekonesans', Rocznik Antropologii Historii, ii (2014).

Domarańczyk Daria, 'Czy kobiety nauki to kobiety sukcesu? Polki i ich dokonania w pedagogice i psychologii na przełomie XIX i XX wieku', in Izabela Desperak, Inga Kuźma (eds.), Kobiety niepokorne: reformatorki - buntowniczki - rewolucjonistki: herstorie (Łódź 2017).

Kałwa Dobrochna, Kobieta aktywna w Polsce międzywojennej. Dylematy środowisk kobiecych (Kraków, 2001).

Kosmowska Irena, Milkuszyc Dorota and Szycówna Aniela, Kobieta polska jako autorka pedagogiczna: bibljografja książek $z$ dziedziny teorii wychowania, podręczników $i$ literatury dla młodzieży, poprzedzona wstępem historycznym (Warszawa, 1912). 
Krzywicki Ludwik, Wspomnienia, i, iii (Warszawa, 1947, 1959).

Michalski Grzegorz, Zygmunt Mysłakowski (1890-1971): działalność i twórczość pedagogiczna, (Łódź, 1994).

Owadowska Renata, Zofia Daszyńska-Golińska: o nurt reformistyczny w polityce społecznej (Poznań, 2004).

Pamiętnik Polskiego T-wa badań nad dziećmi za rok 1912 (Warszawa, 1913).

Radlińska Helena, 'Listy o nauczaniu i pracy badawczej', in eadem (ed.), Z dziejów pracy społecznej $i$ oświatowej (Wrocław, 1964).

Theiss Wiesław, 'Udział Heleny Radlińskiej w europejskim ruchu społeczno-pedagogicznym (1918-1939)', Society Register, i (2017).

Więcławski Włodzimierz, Stownik biograficzny socjologii polskiej, i-iv (Toruń, 20012011).

Wołoszyn Stefan, Nauki o wychowaniu w Polsce w XX wieku: próba syntetycznego zarysu na tle powszechnym (Kielce, 1998).

Zysiak Agata, Punkty za pochodzenie. Powojenna modernizacja $i$ uniwersytet $w$ robotniczym mieście (Kraków, 2016).

Aneta Boldyrew - history of education and pedagogical ideas; professor at the Faculty of Educational Science, University of Łódź; e-mail: bow0@poczta.onet.pl 